International Research Journal of Management, IT \& Social Sciences
Available online at https://sloap.org/journals/index.php/irjmis/
Vol. 9 No. 1, January 2022, pages: 138-150
ISSN: 2395-7492
https://doi.org/10.21744/irjmis.v9n1.2017

\title{
The Effect of Accountability, Transparency and Operational Efficiency on Decisions to Pay Zakat with Ability as Intervening Variables
}

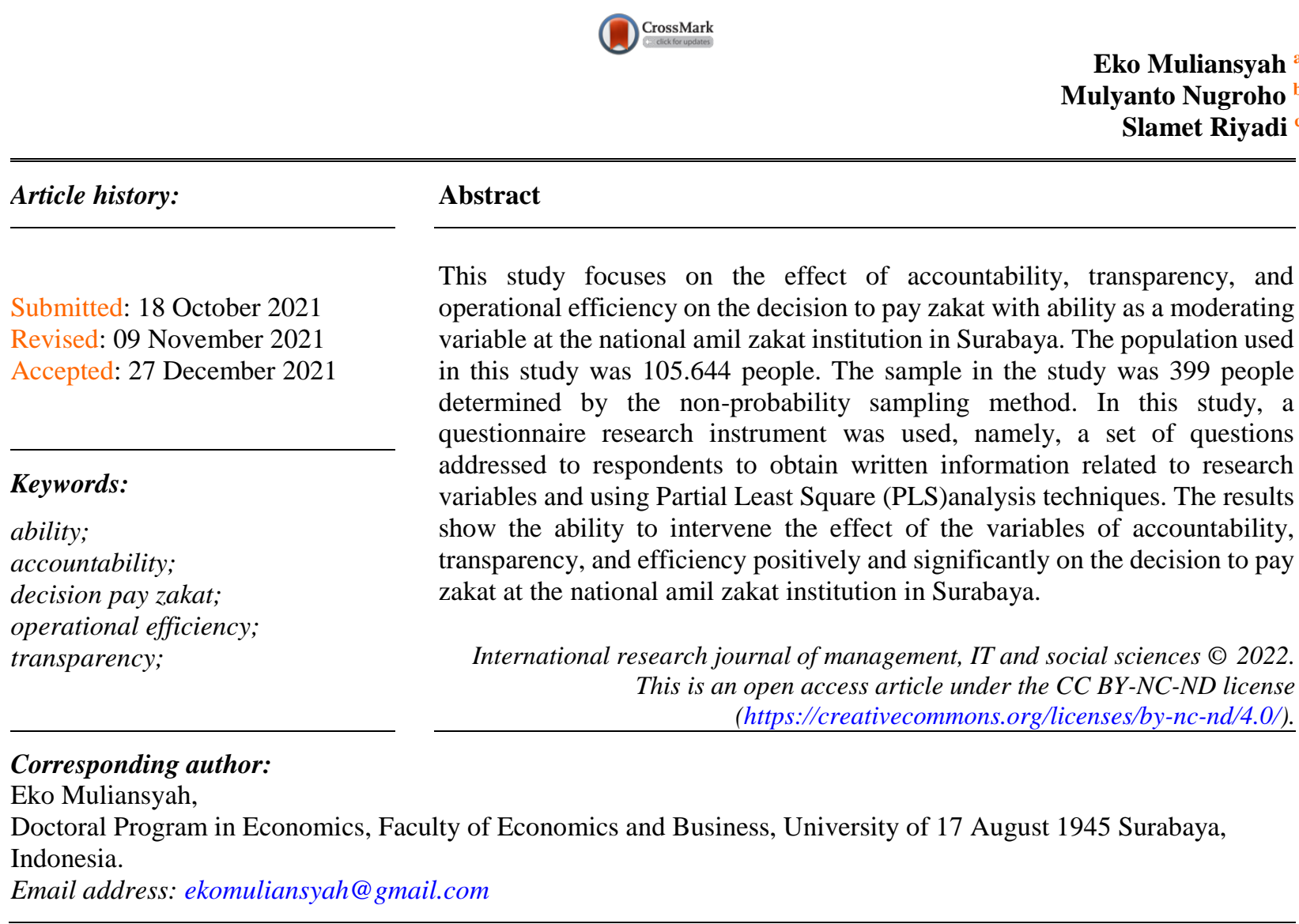

\footnotetext{
a Doctoral Program in Economics, Faculty of Economics and Business, University of 17 August 1945 Surabaya, Indonesia

Doctoral Program in Economics, Faculty of Economics and Business, University of 17 August 1945 Surabaya, Indonesia Doctoral Program in Economics, Faculty of Economics and Business, University of 17 August 1945 Surabaya, Indonesia 


\section{Introduction}

The Amil Zakat Institution (LAZ) is a religious institution whose task is to collect and distribute zakat (Laka \& Suprasto, 2020; Yusroni \& Chadhiq, 2021). The zakat amils are officials appointed by the government to audit zakat assets and travel to various regions, the tribes where there are property owners, then zakat assets are taken from the amil brands, they are given zakat according to their work and business based on the government's assessment. (Majmu' Fatawa Ibn Baz, 14/14). Their "zakat amil" are people appointed by the imam - the government - to collect zakat and distribute it to zakat mustahiq. They are amil over zakat assets, meaning they have authority over zakat assets. While the representative for people who have property, for example this rich person says to his friend, 'Oh so and so, please take my zakat and please distribute it to the poor ..' then this kind of amil is not amil. Because of this the status is only representative, who is in charge of zakat and has no authority over zakat assets. (Fatawa Nur ala ad-Darb, 29/206)

The urgency of financial statements in a financial institution is very important because the financial statements are a reflection of the achievements of management in a certain period. By looking at the financial statements of a company, we can see how the performance of management during that period. In managing a zakat institution, apart from being able to present the credibility of the audit report, it also focuses on the effectiveness and efficiency of funds for program purposes. "Philanthropy management is not only due to the low credibility of public auditing, but it refers to the effectiveness and efficiency of funds for program objectives. It is particularly concerning that while donors are more concerned with the efficiency and objectives of the program, public auditing only provides finance-related information" (Jahar, 2010).

Accountability is one of the main elements of the realization of good governance which is currently being pursued in Indonesia. Accountability and transparency of financial statements are one of the indicators to assess the performance of public organizations, both for-profit and non-profit. One of the easiest forms of accountability to see is the existence of financial reports and the disclosure of financial statements and easily accessible to the public and muzzaki in a zakat institution is a form of transparency in financial reports. The financial statements prepared must comply with the accounting for zakat, namely PSAK 109. Zakat accounting is a must for zakat management in accordance with sharia rules and at the same time to meet the demands and provisions of good governance which includes transparency and accountability (Astuti \& Asrori, 2016). For that reason, it is said that the interest in paying professional zakat is determined by the accountability and transparency of financial reports.

Several studies on transparency and accountability from several researchers such as that conducted by Pangestu \& Jayanto (2017), found that the variables of transparency and accountability have a positive and significant influence on motivation to pay zakat in Semarang. Nurhayati et al. (2018), revealed that transparency has a significant effect on the level of acceptance of zakat funds, but accountability has no significant effect on the level of acceptance of zakat funds. Meanwhile, research conducted by Aedy (2015), reveals that there is no proven transparency in the management of zakat which is managed by zakat management organizations. Amil zakat institutions should minimize operational costs so that zakat funds can be distributed to seven other asnaf with a larger portion. The results of Rahman's (2015), research stated that zakat funds used for administrative costs were still high at $18 \%$ of the total zakat funds distributed. This shows that administrative costs are still high, even exceeding the stipulated rules.

Administrative costs borne by the government, such as in Jordan, Egypt, Kuwait, and Sudan, so that zakat funds distributed more optimally do not automatically apply to Indonesia (Faseruk \& Hossain, 2017; Nikmatuniayah, 2014). It can be found that the percentage of zakat administration costs at Baznas in four districts on average is still above twelve and a half percent (12.5\%), although the source of funds taken from zakat funds is very low, ranging from seven percent $(7 \%)$ to eight. percent $(8 \%)$ of the total zakat funds received, but to cover the shortfall it is taken from infaq/sadaqah funds, Regional Revenue and Expenditure Budget funds (APBD), and State Revenue and Expenditure Budget funds (APBN).

One of the fundamental factors of a decision is intention. The intention is an important element to accept or reject certain behaviors (Muhammad \& Saad, 2016). In terminology, intentions are mental devices consisting of feelings, hopes, beliefs, prejudices, and other tendencies that direct individuals to certain choices (Nur'aini \& Ridla, 2015). Crow $\&$ Crow formulate three factors in intention (Saleh, 2004), as follows: a. An impulse within us, this factor is because the need is related to body and soul $b$. Social motives, need recognition from the environment to create the intention to do something c. Emotional factors, intentions related to emotions, and the intensity to pay attention to something.

Although there are several driving factors There are three aspects in zakat policy, they are religious, moral, and social. From the religious aspect, paying zakat means that we have done a third of the five pillars of Islam. Zakat is a way to get closer to Allah, get reward and mercy. From the moral aspect, paying zakat can instill kindness, show

Muliansyah, E., Nugroho, M., \& Riyadi, S. (2022). The effect of accountability, transparency and operational efficiency on decisions to pay zakat with ability as intervening variables. International Research Journal of Management, IT and Social Sciences, 9(1), 138-150. https://doi.org/10.21744/irjmis.v9n1.2017 
affection, and eliminate feelings (Lourenço, 2015; Ali et al., 2014; Hassan, 2015). In the social aspect, zakat can help others, provide support to mustahiq, and increase economic growth and wealth (Mutmainah, 2015). The determination of the ability to pay zakat has been classified in a religious regulation regarding the mandatory conditions for people to take zakat. So for people who are not in the character of that ability, there is no obligation and there is no need to participate in donating zakat either directly or through amil zakat institutions.

But this ability side is multi-interpreted so that anyone who mathematically calculates a person can be classified as obligatory zakat can avoid it on the grounds that the burden of the costs borne is very large. Of course, this ability will affect the education of amil zakat institutions to inspire muzzaki to participate in their program. In the study, Jayanto \& Munawaroh (2019), showed that there was no significant effect on interest in paying professional zakat, but Mutmainah (2015), stated that accountability and transparency had a significant positive effect on paying Zakat. Then Amilahaq \& Ghoniyah (2019), states that the behavioral control received has no effect on behavior. Even so, it requires moderating other variables that drive zakat decisions.

While previous research, namely in Ardiani (2019); Al Parisi (2017); Wahyuni, (2016); Akbar (2009); Rusydiana \& Al Farisi (2016), all examined qualitatively operational efficiency. in several national and regional medical institutions. So that quantitative research is needed to enrich the previous research. From the research mentioned above, there is a gap that encourages researchers to re-examine dissertation research, namely, there is a positive influence in one study but there is a negative effect in other studies. In previous research, it was also stated that moderating variables were needed to shape the behavior of paying zakat. Based on the explanation above, the author will focus on examining the effect of professional zakat management on people's decisions to pay zakat, infaq, and alms in zakat institutions. Several factors influence it; Accountability, transparency, and operational efficiency can be used as measures for people to decide to pay zakat, infaq, and alms to zakat institutions with the ability as moderating variables (Groenhart \& Bardoel, 2012; Gray, 1992; Williams, 2015).

In this study there is novelty or novelty from previous research, it is with the ability variable as moderating variables that have never been raised in previous research, a conceptual framework that is different from previous research, the place of research, and new research subjects will certainly bring up a new paradigm in viewing the results of this study. This research is interesting and urgent to do because Indonesia is one of the countries where the majority of the population is Muslim, the poverty rate is high, and the realization of zakat distribution is still low. In the Islamic perspective, poverty is sunatullah. Poverty alleviation requires empowerment efforts from the bottom up that involve all social elements through mutual help behavior (Ridlwan \& Sukmana, 2017).

\section{Literature review and hypotheses development}

The higher the accountability of an institution it will increase a person's interest. Accountability can affect a person's interest in paying zakat. In implementing accountability, management is asked to provide information to the public. The information needed is related to accounting because in it there are financial statements that become a reference in implementation. This will have an impact on a person's interest in choosing a good financial report and also at the same time in line with the theory of interest, namely an impulse in a person based on curiosity. Research by Kabib et al. (2021), stated that the interest of muzakki was significantly influenced by accountability. Yuliafitri \& Khoiriyah (2016), state that the decision to pay zakat is influenced by accountability. INTAN SURI MAHARDIKA PERTIWI (2021), in her research, proves that accountability has a positive influence on improving decisions to pay zakat.

\section{H1: Accountability has a significant effect on the decision to pay zakat at the national amil zakat institution in Surabaya.}

Accountability is defined as the obligation that gives the mandate to present, report, and give responsibility for the disclosure of activities that are borne by having the authority and right to demand accountability. Amilahaq \& Ghoniyah (2019), Accepted behavioral control has no effect on behavior. However, education and outreach to muzakki are still needed. Research by Jumarni et al. (2019), suggests that muzakki's interest is significantly influenced by accountability with the influence of ability. Kabib et al. (2021), stated that the decision to pay zakat is influenced by accountability with ability as an intervening variable. Fitria \& Romdhoni (2021), in her research proves that accountability has a positive influence on improving decisions to pay zakat with ability as an intervening.

H2: accountability has a significant effect on the decision to pay zakat with ability as an intervening variable at the national amil zakat institution in Surabaya 
Public accountability is an obligation of zakat management organizations (OPZ), namely by providing regular reports to the public, including muzakki (Yuliafitri \& Khoiriyah, 2016). This report is a strategy in order to increase accountability with the trend of financial planning patterns carried out based on the order of fulfillment of consumption needs and transparency to muzakki and especially to God so that it will lead to trust in muzakki. The higher the transparency of an institution it will increase one's trust. The transparency of a Zakat Management Institution will affect the interest of muzakki. This is because there is an urge within a person to choose a transparent institution. So this is in line with the theory of interest, namely social motives which means to arouse to carry out certain activities. Research by Kabib et al. (2021), stated that the interest of muzakki was significantly influenced by transparency. Yuliafitri \& Khoiriyah (2016), state that the decision to pay zakat is influenced by transparency. INTAN SURI MAHARDIKA PERTIWI (2021), in her research, proves that transparency has a positive effect on increasing the decision to pay zakat.

\section{H4: transparency has a significant effect on the decision to pay zakat in institutions.}

Theoretically, the understanding and several provisions are explained so that it can be related to the first that transparency is a form of protection for muzakki and mustahik by enabling or openness to the public to gain access to important information related to the payment of zakat which of course with the ability possessed helps muzakki to better understand information from the zakat institution which includes finance proves that the institution is legitimate. Research by Jumarni et al. (2019), suggests that muzakki's interest is significantly influenced by transparency with the influence of ability. Kabib et al. (2021), stated that the decision to pay zakat is influenced by transparency with ability as an intervening variable. Fitria \& Romdhoni (2021), in their research, proves that transparency has a positive influence on increasing the decision to pay zakat with the ability as an intervening.

H5: transparency has a significant effect on the decision to pay zakat with ability as an intervening variable at the national amil zakat institution in Surabaya.

Efficiency measurement is very closely related to the performance of non-profit organizations such as zakat institutions. Efficiency is one of the instruments in measuring the performance of institutions that have financial reports. Efficiency measurement is done by comparing the input with the resulting output. With this efficiency analysis, it is possible to find out which one is more efficient in terms of the use of inputs and output expenditures on the performance of non-profit organizations such as the amil zakat agency. Research by Jumarni et al. (2019), suggests that the interest of muzakki is significantly influenced by operational efficiency. Kabib et al. (2021), stated that the decision to pay zakat is influenced by operational efficiency. Fitria \& Romdhoni (2021), in their research, proves that operational efficiency has a positive influence on improving the decision to pay zakat.

H6: operational efficiency has a significant effect on the decision to pay zakat at the national amil zakat institution in Surabaya

Zakat institutions must implement a good accountability system, thus the management of zakat institutions is an important factor in optimizing the resources owned by zakat management institutions. Understanding Through efficiency analysis methods can increase muzakki's knowledge of which OPZs have been efficient in terms of the use of inputs and outputs of zakat institutions (Jumarni et al., 2019). Research by Yuliafitri \& Khoiriyah (2016), states that the decision to pay zakat is influenced by operational efficiency with the influence of ability as an intervening variable. Kabib et al. (2021), stated that muzakki's interest was significantly influenced by operational efficiency which was directly influenced by ability as an intervening variable. INTAN SURI MAHARDIKA PERTIWI (2021), in her research, proves that ability as an intervening variable affects the relationship between operational efficiency to improve the decision to pay zakat. Based on this opinion, this hypothesis is as follows.

H7: operational efficiency has a significant effect on the decision to pay zakat with ability as an intervening variable at the national amil zakat institution in Surabaya

Muliansyah, E., Nugroho, M., \& Riyadi, S. (2022). The effect of accountability, transparency and operational efficiency on decisions to pay zakat with ability as intervening variables. International Research Journal of Management, IT and Social Sciences, 9(1), 138-150. https://doi.org/10.21744/irjmis.v9n1.2017 


\section{Materials and Methods}

Research place at the National Amil Zakat institution with a branch office in Surabaya. From the data of all amil zakat institutions recorded at the Ministry of Religion of the Republic of Indonesia, it turns out that there are only 12 amil zakat institutions that have representative offices in Surabaya. The population used in this study were all registered donors at the amil zakat institution which has a representative office in Surabaya a number of 105,644 people. The sample in this study was determined by the non-probability sampling method, which is a sampling technique that does not provide equal opportunities or opportunities for each member of the population to be a sample, with a sampling technique of 399 samples (Ahmad et al., 2015; Saad et al., 2014; Roberts, 2009). The research hypothesis was tested using a Structural Equation Model (SEM) approach based on Partial Least Square (PLS). PLS is a component or variant-based structural equation model (SEM). Structural Equation Model (SEM) is a field of statistical study that can test a series of relationships that are relatively difficult to measure simultaneously.

\section{Results and Discussions}

\section{Evaluation of outer model or measurement model}

Before discussing the significance of the direct effect of each exogenous variable on the endogenous variables in the research model, the validity of the model is discussed first. There are three criteria in the use of data analysis techniques with Smart PLS to assess the outer model, namely convergent validity, discriminant validity, and composite reliability.

\section{Outlierity evaluation}

The use of data analysis techniques using Smart PLS. The outer model is assessed by looking at the convergent validity (the magnitude of the loading factor for each construct). This study uses a minimum loading factor limit of 0.5 .

Table 1

Outer loadings

\begin{tabular}{|c|c|c|c|c|c|}
\hline \multirow{2}{*}{$\begin{array}{l}\text { Variable } \\
\text { Indicator }\end{array}$} & \multicolumn{5}{|c|}{ Variable } \\
\hline & $\begin{array}{l}\text { Decision to Pay } \\
\text { Zakat }\end{array}$ & Accountability & transparency & $\begin{array}{l}\text { Operational } \\
\text { Efficiency }\end{array}$ & Ability \\
\hline $\mathrm{X} 1.1$ & & 0.770 & & & \\
\hline $\mathrm{X} 1.2$ & & 0.709 & & & \\
\hline $\mathrm{X} 1.3$ & & 0.771 & & & \\
\hline $\mathrm{X} 1.4$ & & 0.725 & & & \\
\hline $\mathrm{X} 1.5$ & & 0.727 & & & \\
\hline $\mathrm{X} 1.6$ & & 0.674 & & & \\
\hline $\mathrm{X} 1.7$ & & 0.771 & & & \\
\hline $\mathrm{X} 1.8$ & & 0.671 & & & \\
\hline $\mathrm{X} 1.9$ & & 0.788 & & & \\
\hline $\mathrm{X} 2.1$ & & & 0.777 & & \\
\hline $\mathrm{X} 2.2$ & & & 0.702 & & \\
\hline $\mathrm{X} 2.3$ & & & 0.732 & & \\
\hline $\mathrm{X} 2.4$ & & & 0.720 & & \\
\hline$X 2.5$ & & & 0.758 & & \\
\hline X2.6 & & & 0.689 & & \\
\hline $\mathrm{X} 2.7$ & & & 0.814 & & \\
\hline X3.1 & & & & 0.765 & \\
\hline X3.2 & & & & 0.657 & \\
\hline X3.3 & & & & 0.757 & \\
\hline X3.4 & & & & 0.718 & \\
\hline $\mathrm{X} 3.5$ & & & & 0.793 & \\
\hline
\end{tabular}




\begin{tabular}{|c|c|c|c|}
\hline X3.6 & & 0.682 & \\
\hline X3.7 & & 0.773 & \\
\hline Y1.1 & 0.830 & & \\
\hline Y 1.2 & 0.749 & & \\
\hline Y1.3 & 0.862 & & \\
\hline Y1.4 & 0.762 & & \\
\hline Y1.5 & 0.696 & & \\
\hline Y1.6 & 0.800 & & \\
\hline Z1.1 & & & 0.780 \\
\hline Z1.2 & & & 0.642 \\
\hline Z1.3 & & & 0.808 \\
\hline Z1.4 & & & 0.657 \\
\hline Z1.5 & & & 0.722 \\
\hline Z1.6 & & & 0.744 \\
\hline Z1.7 & & & 0.814 \\
\hline Z1.8 & & & 0.728 \\
\hline Z1.9 & & & 0.796 \\
\hline
\end{tabular}

Primary Data, 2021

The processing results are as shown in table 1 which shows that the indicator decisions to pay zakat, accountability, transparency, operational efficiency and ability, have outer loadings value of more than 0.5. Transparency is the strongest measure of the decision variable to pay zakat because it has the highest outer loadings value (0.814). So it can be concluded that these five variables are valid variables to measure the decision variable to pay zakat (Ida $\&$ DWINTA, 2010; Susilowati \& Setyorini, 2018).

\section{Discriminant validity}

Discriminant validity of the measurement model with reflective indicators (factors) assessed based on the cross-loading of measurements with the construct. If the construct's correlation with the measurement item is greater than the size of the other constructs, then this indicates that the latent construct predicts the size of their block better than the size of the other blocks. The results of the Discriminant validity measurement are as shown in Table 2.

Table 2

Discriminant validity

\begin{tabular}{lll}
\hline Variable & AVE . coefficient & Description \\
\hline Decision to Pay Zakat & 0.616 & Valid \\
Accountability & 0.540 & Valid \\
transparency & 0.552 & Valid \\
Operational Efficiency & 0.542 & Valid \\
Ability & 0.556 & Valid \\
\hline
\end{tabular}

Primary Data, 2021

The data in Table 2 can be explained that from the results of the six variables, the AVE value is above 0.50 from the correlation coefficient between one variable and another, so it can be said that the data has good discriminant validity.

\section{Composite reliability}

According to Aedy (2015), that the reliability of a construct can be assessed from composite reliability which serves to measure internal consistency whose value must be above 0.60 and compare the AVE root with correlations between constructs with a value that must be above 0.50 .

Muliansyah, E., Nugroho, M., \& Riyadi, S. (2022). The effect of accountability, transparency and operational efficiency on decisions to pay zakat with ability as intervening variables. International Research Journal of Management, IT and Social Sciences, 9(1), 138-150. https://doi.org/10.21744/irjmis.v9n1.2017 
Table 3

Composite reliability

\begin{tabular}{lll}
\hline No & Variable & Composite Reliability \\
\hline 1 & Decision to Pay Zakat & 0.905 \\
2 & Accountability & 0.913 \\
3 & Transparency & 0.896 \\
4 & Operational Efficiency & 0.892 \\
5 & Ability & 0.918 \\
\hline
\end{tabular}

Primary Data, 2021

Table 3 shows that the composite reliability value of all constructs, which is above 0.60 , has met the reliable criteria. Based on the overall evaluation results, both convergent, discriminant validity, composite reliability. which has been described above, it can be concluded that the indicators as a measure of the latent variable are valid and reliable measures.

Structural model testing (inner model)

Table 4

R-Squares. value

\begin{tabular}{lll}
\hline & \\
\hline 1 & Decision to Pay Zakat & 0.839 \\
2 & Ability & 0.884 \\
\hline
\end{tabular}

Primary Data, 2021

The R-square value of the decision variable to pay zakat is 0.839 in Table 4 , it can be interpreted that 83.9 percent of the variability of the decision construct to pay zakat is explained by the variable ability, while 16.1 percent of the decision variables to pay zakat are explained by variables outside the model. Likewise, the ability variable 88.4 percent of the variability is explained by the decision to pay zakat, while 11.6 percent of the ability variable is explained by variables outside the model. In addition to using the R-square. The goodness of fit of the model is also measured using the Q-Square predictive relevance for the structural model, measuring how well the observed values are generated by the model and also the estimated parameters (Al-Ayubi \& Possumah, 2018; Hakim, 2014; Alim, 2015).

Q-square value > 0 indicates the model has predictive relevance; on the other hand if the value of Q-Square 0 indicates the model lacks predictive relevance. Q-Square calculation is done by the formula:

$$
\mathrm{Q} 2=1-\left(1-\mathrm{R} 1^{2}\right)\left(1-\mathrm{R} 2^{2}\right)
$$

where $\mathrm{R} 1^{2}, \mathrm{R} 2^{2}, \mathrm{R} 3^{2}$ are the $\mathrm{R}$-square of the endogenous variables.

The magnitude of $\mathrm{Q} 2$ has a value with a range of $0<\mathrm{Q} 2<1$ where the closer to 1 means the better the model. The quantity of Q2 is equivalent to the coefficient of total determination in path analysis. The calculation of the goodness of fit model is as follows:

$$
\begin{aligned}
\mathrm{Q} 2 & =1-\left(1-\mathrm{R} 1^{2}\right)\left(1-\mathrm{R} 2^{2}\right) \\
& =1-(1-0.839)(1-0.884) \\
& =1-(0.161)(0.116) \\
& =1-0.0186 \\
& =0.981
\end{aligned}
$$

Based on the calculation above, 98.1 percent connect the decision variable to pay zakat which is explained by the variable ability and, while the remaining 1.9 percent is explained by variables not included in the model. The structural model is called a reflexive model in which the covariance of indicator measurements is influenced by latent constructs or reflects variations from unidimensional constructs depicted by ellipses with several arrows from 
construct to indicator. This model hypothesizes that changes in latent constructs will affect changes in indicators. In this model there are three exogenous variables, namely the variable accountability, transparency, and operational efficiency, a mediating variables, namely ability, endogenous variables in the decision to pay zakat. The six variables have their respective indicators.

\section{Hypothesis test}

Variable influence path coefficient The effect of accountability, transparency, operational efficiency on the decision to pay zakat at the national amil zakat institution in Surabaya and the role of mediating ability on the effect of accountability, transparency, operational efficiency on the decision to pay zakat at the national amil zakat institution in Surabaya, are presented in Table 5.

Table 5

Result for inner model

\begin{tabular}{|c|c|c|c|c|c|}
\hline $\begin{array}{l}\text { Influence } \\
\text { Direct }\end{array}$ & $\begin{array}{l}\text { Original } \\
\text { Sample }(\mathrm{O})\end{array}$ & $\begin{array}{l}\text { Sample } \\
\text { Mean (M) }\end{array}$ & $\begin{array}{l}\text { Standard Deviation } \\
\text { (STDEV) }\end{array}$ & $\begin{array}{l}\text { T Statistics } \\
(|\mathrm{O} / \mathrm{STDEV}|)\end{array}$ & Description \\
\hline $\begin{array}{l}\text { Accountability - } \\
\text { Decision to Pay Zakat }\end{array}$ & 0.365 & 0.368 & 0.062 & 5,930 & Significant \\
\hline $\begin{array}{l}\text { Accountability - Ability } \\
\text {-Decision to Pay Zakat }\end{array}$ & 0.098 & 0.101 & 0.030 & 3.303 & Significant \\
\hline $\begin{array}{l}\text { Transparency - Decision } \\
\text { to Pay Zakat }\end{array}$ & 0.160 & 0.154 & 0.062 & 2,566 & Significant \\
\hline $\begin{array}{l}\text { Transparency - Ability - } \\
\text { Decision to Pay Zakat }\end{array}$ & 0.071 & 0.073 & 0.026 & 2,792 & Significant \\
\hline $\begin{array}{l}\text { Efficiency - Decision to } \\
\text { Pay Zakat }\end{array}$ & 0.407 & 0.411 & 0.069 & 5.889 & Significant \\
\hline $\begin{array}{l}\text { Efficiency - Ability - } \\
\text { Decision to Pay Zakat }\end{array}$ & 0.102 & 0.103 & 0.030 & 3.469 & Significant \\
\hline
\end{tabular}

Primary Data, 2021

In this study, the T-table value was obtained with a significance of 5\%, the T-table was 1.96 , taking into account the path coefficients in Table 5, it turns out that the t-statistical value above 1.96 can be interpreted in this test as a significant effect. The discussion of each hypothesis is presented in the following subsection.

\section{Accountability effect on the decision to pay zakat}

Accountability has a significant effect on the decision to pay zakat at the national amil zakat institution in Surabaya. Table 5 shows that there is an effect of accountability on the decision to pay zakat at the national amil zakat institution in Surabaya at 0.365 , with a t-statistic value of 5.930 which is greater than the T-table of 1.96. This means that wellorganized accountability has a significant positive effect on the decision to pay zakat at the national amil zakat institution in Surabaya by 0.365 . This means that hypothesis 1 is accepted.

The descriptive description shows that accountability in the decision to pay zakat at the national amil zakat institution in Surabaya reaches a strong original sample value (0.365). These results indicate that accountability as an ethical concept that is close to administration related to public interest with accountability, the ability to provide answers influences on increasing the decision to pay zakat at the national amil zakat institution in Surabaya.

The results of this study are in accordance with Mutmainah's (2015), study in which a study produced a partial test that accountability and transparency had a significant positive effect on the intention to pay Zakat, so there was no effect of responsibility. Jayanto \& Munawaroh (2019), in their research, show that there is a significant effect of accountability on the decision to pay zakat. Research by Kabib et al. (2021), stated that the interest of muzakki was significantly influenced by accountability. Yuliafitri \& Khoiriyah (2016), state that the decision to pay zakat is influenced by accountability. INTAN SURI MAHARDIKA PERTIWI (2021), in her research, proves that accountability has a positive influence on improving decisions to pay zakat.

Muliansyah, E., Nugroho, M., \& Riyadi, S. (2022). The effect of accountability, transparency and operational efficiency on decisions to pay zakat with ability as intervening variables. International Research Journal of Management, IT and Social Sciences, 9(1), 138-150. https://doi.org/10.21744/irjmis.v9n1.2017 
Ability moderating the effect of accountability on the decision to pay zakat

Accountability for the decision to pay zakat through ability as an intervening variable at the national amil zakat institution in Surabaya. Table 5 shows that the ability variable moderates the effect of accountability on the decision to pay zakat at the national amil zakat institution in Surabaya, 0.098, with a t-statistic value of 3.303, which is greater than the T-table of 1.96. This means that everyone's ability to moderate the effect of significant positive accountability on the decision to pay zakat at the national amil zakat institution in Surabaya is 0.098. This means that hypothesis 2 is accepted.

The descriptive description shows that ability is an intervening variable for the influence of accountability on the decision to pay zakat at the national amil zakat institution in Surabaya, achieving a strong original sample value (0.098). These results indicate that socioeconomic status refers to a person's family income, education and occupation, which can influence accountability as an ethical concept to improve decisions to pay zakat at the national amil zakat institution in Surabaya.

The results of this study are in accordance with Agus Zainul Arifin's (2017), research whose research proves that control ability has an influence on the accountability related to the decision to pay zakat. Pangestu \& Jayanto (2017), in their research, states that there is a moderating ability relationship on the effect of accountability on the decision to pay zakat. Kabib et al. (2021), stated that the decision to pay zakat is influenced by accountability with ability as an intervening variable. Fitria \& Romdhoni (2021), in their research, proves that accountability has a positive influence on improving decisions to pay zakat with ability as an intervening.

\section{Transparency effect on the decision to pay zakat}

Transparency has a significant effect on the decision to pay zakat at the national amil zakat institution in Surabaya. Table 5 shows that there is an effect of transparency on the decision to pay zakat at the national amil zakat institution in Surabaya, 0.160, with a t-statistic value of 2.566 which is greater than the T-table of 1.96. This means that the transparency given to each member has a significant positive effect on the decision to pay zakat at the national amil zakat institution in Surabaya by 0.160. This means that hypothesis 4 is accepted. The descriptive description shows that transparency has an effect on the decision to pay zakat at the national amil zakat institution in Surabaya, reaching a strong original sample value (0.160). These results indicate that reputation, financial statement transparency, religiosity and trust have a positive and significant effect on interest in paying professional zakat as a result of the study by Jayanto \& Munawaroh (2019).

The results of the study according to Pangestu \& Jayanto (2017), found that the variables of transparency and accountability had a positive and significant influence on the motivation to pay zakat in Semarang. Nurhayati et al. (2018), revealed that transparency has a significant effect on the level of acceptance of zakat funds, but accountability does not have a significant effect on the level of receipt of zakat funds. Research by Kabib et al. (2021), stated that the interest of muzakki was significantly influenced by transparency. Yuliafitri \& Khoiriyah (2016), state that the decision to pay zakat is influenced by transparency. INTAN SURI MAHARDIKA PERTIWI (2021), in her research proves that transparency has a positive effect on increasing the decision to pay zakat.

\section{Ability moderate the effect of transparency on the decision to pay zakat}

Transparency of the decision to pay zakat through ability as an intervening variable at the national amil zakat institution in Surabaya. Table 5 shows that the ability variable moderates the effect of transparency on the decision to pay zakat at the national amil zakat institution in Surabaya, 0.071, with a t-statistic value of 2.792, which is greater than the T-table of 1.96. This means that everyone's ability to moderate the effect of significant positive transparency on the decision to pay zakat at the national amil zakat institution in Surabaya is 0.071 . This means that hypothesis 5 is accepted.

The descriptive description shows that ability is an intervening variable for the effect of transparency on the decision to pay zakat at the national amil zakat institution in Surabaya, achieving a strong original sample value (0.071). These results indicate that the social status of each individual has an influence on the transparency relationship so as to improve the decision to pay zakat at the national amil zakat institution in Surabaya. The results of this study are in accordance with Sari's (2017), research, which states that social status is able to moderate the effect of transparency on the decision to pay zakat. Hunjra \& Rehman (2016), stated that ability has a positive influence on the transparency relationship on the decision to pay zakat. Research by Jumarni et al. (2019), suggests 
that muzakki's interest is significantly influenced by transparency with the influence of ability. Kabib et al. (2021), stated that the decision to pay zakat is influenced by transparency with ability as an intervening variable. Fitria \& Romdhoni (2021), in their research, proves that transparency has a positive influence on increasing the decision to pay zakat with the ability as an intervening.

\section{Efficiency on the decision to pay zakat}

Operational efficiency has a significant effect on the decision to pay zakat at the national amil zakat institution in Surabaya. Table 5 shows that there is an effect of operational efficiency on the decision to pay zakat at the national amil zakat institution in Surabaya, 0.407, with a t-statistic value of 5.889 which is greater than the T-table of 1.96. This means that a well-organized operational efficiency has a significant positive effect on the decision to pay zakat at the national amil zakat institution in Surabaya by 0.407 . This means that hypothesis 7 is accepted. The descriptive description shows that efficiency affects the decision to pay zakat at the national amil zakat institution in Surabaya, reaching a strong original sample value (0.407). These results indicate that when the efficiency level of each individual goes well, it certainly has a positive influence on increasing the decision to pay zakat.

The results of this study are in accordance with Wahyuni (2016). This study shows that through measurement with a production approach, inefficiency has a positive influence on the decision to pay zakat. Rusydiana \& $\mathrm{Al}$ Farisi (2016), found that of the three zakat management organizations 12 decision-making units are efficient in improving decisions to pay zakat positively. Research by Jumarni et al. (2019), suggests that the interest of muzakki is significantly influenced by operational efficiency. Kabib et al. (2021), stated that the decision to pay zakat is influenced by operational efficiency. Fitria \& Romdhoni (2021), in their research, proves that operational efficiency has a positive influence on improving the decision to pay zakat.

\section{Ability moderating the effect of efficiency on the decision to pay zakat}

Operational efficiency on the decision to pay zakat through ability as an intervening variable at the national amil zakat institution in Surabaya. Table 5 shows that the ability variable moderates the effect of operational efficiency on the decision to pay zakat at the national amil zakat institution in Surabaya, 0.102, with a t-statistic value of 3.469, which is greater than the T-table of 1.96. This means that everyone's ability to moderate the effect of significant positive operational efficiency on the decision to pay zakat at the national amil zakat institution in Surabaya is 0.102. This means that hypothesis 8 is accepted.

The descriptive description shows that ability is an intervening variable for the effect of efficiency on the decision to pay zakat at the national amil zakat institution in Surabaya, achieving a strong original sample value (0.102). These results indicate that the social status of each individual has an influence on the relationship between the efficiency of the use of zakat so as to improve the decision to pay zakat at the national amil zakat institution in Surabaya. The results of this study are in accordance with Al Parisi (2017), which results that a person's ability influences the relationship between the efficiency of the use of zakat so as to improve the decision to pay zakat. Wahyuni (2016), a good ability in each individual will certainly increase efficiency in a positive way that can increase the decision to pay zakat. Research by Yuliafitri \& Khoiriyah (2016), states that the decision to pay zakat is influenced by operational efficiency with the influence of ability as an intervening variable. Kabib et al. (2021), stated that muzakki's interest was significantly influenced by operational efficiency which was directly influenced by ability as an intervening variable.

\section{Conclusion}

This research can be considered as the development of organizational behavior theory in the study of economics, especially the theory of accountability, efficiency, transparency and ability decisions to pay zakat. The variables of accountability, efficiency, transparency, ability have a significant positive effect on the decision to pay zakat at the national amil zakat institution in Surabaya. Ability is able to moderate the effect of accountability, efficiency, transparency on the decision to pay zakat at the national amil zakat institution in Surabaya. The results of this study have implications for the development of economics, especially in the field of economics related to aspects of accountability, efficiency, transparency, ability, where these variables can be used as a tool to improve decisions to

Muliansyah, E., Nugroho, M., \& Riyadi, S. (2022). The effect of accountability, transparency and operational efficiency on decisions to pay zakat with ability as intervening variables. International Research Journal of Management, IT and Social Sciences, 9(1), 138-150. https://doi.org/10.21744/irjmis.v9n1.2017 
pay zakat. These results can be used as a reference in order to improve the decision to pay zakat at the national amil zakat institution in Surabaya. The application of the theory development generated in this study shows that financial ability moderates zakat decisions.

\section{Conflict of interest statement}

The authors declared that's they have no competing interests.

Statement of authorship

The authors have a responsibility for the conception and design of the study. The authors have approved the final article.

\section{Acknowledgments}

We are grateful to two anonymous reviewers for their valuable comments on the earlier version of this paper. 


\section{References}

Aedy, H. (2015). Measuring The Quality of Zakat Management of Government-Endorsed Bodies. International Journal of Science and Research (IJSR), 4(8), 2047-2051.

Agus Zainul Arifin, T. (2017). Turnitin Dr. Ir. Agus Zainul Arifin, MM. The Influence of Financial Knowledge, Control and Income on Individual Financial Behavior. The Influence of Financial Knowledge, Control and Income on Individual Financial Behavior., 20(3A), 635-648.

Ahmad, R. A. R., Othman, A. M. A., \& Salleh, M. S. (2015). Assessing the satisfaction level of zakat recipients towards zakat management. Procedia Economics and Finance, 31, 140-151. https://doi.org/10.1016/S2212$5671(15) 01141-7$

Akbar, N. (2009). Analisis efisiensi organisasi pengelola zakat nasional dengan pendekatan data envelopment analysis. Tazkia Islamic Finance and Business Review, 4 (2), 760â€"784.

Al Parisi, S. (2017). Tingkat efisiensi dan produktivitas lembaga zakat di Indonesia. Esensi: Jurnal Bisnis dan Manajemen, 7(1), 63-72.

Al-Ayubi, S., \& Possumah, B. T. (2018). Examining the efficiency of zakat management: Indonesian zakat institutions experiences. International Journal of Zakat, 3(1), 37-55.

Ali, N. N. M., Taha, R., Embong, M. R., \& Nor, M. N. M. (2014). Developing a multidimensional performance of zakat collection system in East Coast Region. Procedia-Social and Behavioral Sciences, 164, 84-90. https://doi.org/10.1016/j.sbspro.2014.11.054

Alim, M. N. (2015). Utilization and accounting of Zakat for productive purposes in Indonesia: A review. ProcediaSocial and Behavioral Sciences, 211, 232-236. https://doi.org/10.1016/j.sbspro.2015.11.028

Amilahaq, F., \& Ghoniyah, N. (2019). Compliance behavior model of paying zakat on income through zakat management organizations. Share: Jurnal Ekonomi dan Keuangan Islam, 8(1), 114-141.

Ardiani, N. (2019). the Efficiency of Zakat Collection and Distribution: Evidence From Data Envelopment Analysis. Al-Uqud: Journal of Islamic Economics, 3(1), 54.

Astuti, S., \& Asrori, A. (2016). The Analysis of Amil Competency and Its Effects on The Implementation of Zakat on Amil Zakat Institution. Accounting Analysis Journal, 5(3), 248-255.

Faseruk, A., \& Hossain, A. T. (2017). Spirituality in management: Influence of Islamic thoughts and philosophies. South Asian Journal of Human Resources Management, 4(2), 235-244.

Fitria, T. N., \& Romdhoni, A. H. (2021). The Profession of YouTuber: Ethics in the Islamic Economics' Perspective. Jurnal Ilmiah Ekonomi Islam, 7(3), 1602-1606.

Gray, R. (1992). Accounting and environmentalism: an exploration of the challenge of gently accounting for accountability, transparency and sustainability. Accounting, organizations and society, 17(5), 399-425. https://doi.org/10.1016/0361-3682(92)90038-T

Groenhart, H. P., \& Bardoel, J. L. (2012). Conceiving the transparency of journalism: Moving towards a new media accountability currency. Studies in Communication Sciences, $12(1)$, 6-11. https://doi.org/10.1016/j.scoms.2012.06.003

Hakim, M. M. (2014). Pengaruh transparansi dan akuntabilitas pengelolaan zakat terhadap minat muzakki di Rumah Zakat Cabang Semarang (Doctoral dissertation, IAIN Walisongo).

Hassan, N. M. (2015). Do capital assistance programs by Zakat institutions help the poor?. Procedia Economics and Finance, 31, 551-562. https://doi.org/10.1016/S2212-5671(15)01201-0

Hunjra, A. I., \& Rehman, Z. U. (2016). Factors Affecting Investment Decision Mediated By Risk Aversion: A Case of Pakistani Investors. International Journal of Economics and Empirical Research, 4(4), 169-181.

Ida, I. D. A., \& DWINTA, C. Y. (2010). Pengaruh Locus Of Control, financial knowledge, income terhadap financial management behavior. Jurnal Bisnis dan Akuntansi, 12(3), 131-144.

INTAN SURI MAHARDIKA PERTIWI, P. E. R. (2021). Pengaruh Akuntabilitas, Transparasi Dan Kepercayaan Terhadap Minat Masyarakat Membayar Zakat (Studi di BAZNAS Bandar Lampung dan BAZNAS Lampung Tengah) (Doctoral dissertation, UIN RADEN INTAN LAMPUNG).

Jahar, A. S. (2010). Masa Depan Filantropi Islam Indonesia: Kajian Lembaga-lembaga Zakat dan Wakaf.

Jayanto, P. Y., \& Munawaroh, S. (2019). The influences of reputation, financial statement transparency, accountability, religiosity, and trust on interest in paying zakat of profession. Jurnal Dinamika Akuntansi, 11(1), 59-69.

JUMARNI, E., Sucipto, S., \& Anita, E. (2019). Pengaruh Akuntabilitas Dan Transparansi Terhadap Kepercayaan Muzakki Membayar Zakat Di Baznas Kota Jambi (Doctoral dissertation, UIN Sulthan Thaha Saifuddin Jambi).

Muliansyah, E., Nugroho, M., \& Riyadi, S. (2022). The effect of accountability, transparency and operational efficiency on decisions to pay zakat with ability as intervening variables. International Research Journal of Management, IT and Social Sciences, 9(1), 138-150. https://doi.org/10.21744/irjmis.v9n1.2017 
Kabib, N., Al Umar, A. U. A., Fitriani, A., Lorenza, L., \& Mustofa, M. T. L. (2021). Pengaruh Akuntabilitas dan Transparansi Terhadap Minat Muzakki Membayar Zakat di BAZNAS Sragen. Jurnal Ilmiah Ekonomi Islam, 7(1), 341-349.

Laka, M. D. L. M. W., \& Suprasto, H. B. (2020). Accountability, information technology and village performance. International Research Journal of Management, IT and Social Sciences, 7(2), 71-78. https://doi.org/10.21744/irjmis.v7n2.874

Lourenço, R. P. (2015). An analysis of open government portals: A perspective of transparency for accountability. Government information quarterly, 32(3), 323-332. https://doi.org/10.1016/j.giq.2015.05.006

Muhammad, S. A., \& Saad, R. A. J. (2016). Moderating effect of attitude toward Zakat payment on the relationship between moral reasoning and intention to pay Zakat. Procedia-Social and Behavioral Sciences, $219,520-527$. https://doi.org/10.1016/j.sbspro.2016.05.029

Mutmainah, L. L. (2015). The Influence of Accountability, Transparency, and Responsibility of Zakat Institution on Intention to Pay Zakat. Global Review of Islamic Economics and Business, 3(2), 108-119.

Nikmatuniayah, N. (2014). Komparasi Sistem Pengendalian Internal Pengelolaan Lembaga Amil Zakat. Jurnal Akuntansi Multiparadigma, 5(3), 498-510.

Nur'aini, H., \& Ridla, M. R. (2015). Pengaruh Kualitas Pelayanan, Citra Lembaga Dan Religiusitas Terhadap Minat Muzakki Untuk Menyalurkan Zakat Profesi. Jurnal Md, 1(2).

Nurhayati, N., Fadilah, S., Iss, A., \& Oktaroza, M. L. (2018). Pengaruh Kualitas Informasi Akuntansi, Akuntabilitas Dan Transparansi Pelaporan Keuangan Terhadap Tingkat Penerimaan Dana Zakatpada Badan Amil Zakat (Baz) Di Jawa Barat. Prosiding SNaPP: Sosial, Ekonomi Dan Humaniora, 4(1), 577-584.

Pangestu, I., \& Jayanto, P. Y. (2017). Analysis in factors affecting muzakki motivation to pay zakat in Semarang city. Accounting Analysis Journal, 6(1), 94-103.

Rahman, S. (2015). Zakat on retirement and pension plans. International Journal of Islamic and Middle Eastern Finance and Management.

Ridlwan, A. A., \& Sukmana, R. (2017). The determinant factors of motivation to pay zakat in regional amil zakat agency of East Java. KARSA: Journal of Social and Islamic Culture, 25(2), 334-345.

Roberts, J. (2009). No one is perfect: The limits of transparency and an ethic for 'intelligent'accountability. Accounting, Organizations and Society, 34(8), 957-970. https://doi.org/10.1016/j.aos.2009.04.005

Rusydiana, A. S., \& Al Farisi, S. (2016). The efficiency of zakah institutions using data envelopment analysis. AlIqtishad: Jurnal Ilmu Ekonomi Syariah, 8(2), 213-226.

Saad, R. A. J., Aziz, N. M. A., \& Sawandi, N. (2014). Islamic accountability framework in the zakat funds management. Procedia-Social and Behavioral Sciences, $164, \quad 508-515$. https://doi.org/10.1016/j.sbspro.2014.11.139

Saleh, A. R. (2004). Psikologi Suatu Pengantar Dalam Persepsi Islam.

Sari, D. R. (2017). Pengaruh Literasi Keuangan, Pendapatan, dan Pendidikan Terhadap Keputusan Investasi Keluarga Etnis China di Surabaya (Doctoral dissertation, STIE PERBANAS SURABAYA).

Susilowati, D., \& Setyorini, C. T. (2018). Efektivitas tata kelola dana zakat. Jurnal Akuntansi Multiparadigma, 9(2), 346-364.

Wahyuni, I. N. (2016). The efficiency of national zakat organizations management using data envelopment analysis. Journal of Islamic Economics Lariba, 2(1).

Williams, A. (2015). A global index of information transparency and accountability. Journal of Comparative Economics, 43(3), 804-824. https://doi.org/10.1016/j.jce.2014.10.004

Yuliafitri, I., \& Khoiriyah, A. N. (2016). Pengaruh kepuasan Muzakki, transparansi dan akuntabilitas pada lembaga Amil Zakat terhadap loyalitas Muzakki (studi persepsi pada LAZ rumah Zakat). Islamiconomic: Jurnal Ekonomi Islam, 7(2).

Yusroni, N., \& Chadhiq, U. (2021). Understanding the impact of zakat and waqf as economic development of the community in rural areas. International Research Journal of Management, IT and Social Sciences, 8(6), 639-647. https://doi.org/10.21744/irjmis.v8n6.1966 